\title{
ДОСЯГНЕННЯ ТА ПЕРСПЕКТИВИ ОРГАНІЗАЦІЇ НАВЧАЛЬНОГО ПРОЦЕСУ В КОНТЕКСТІ ЄВРОПЕЙСЬКОЇ ІНТЕГРАЦЇ̈ У ВНМУ ім. М. І. ПИРОГОВА
}

\author{
В. М. Мороз, Ю. Й. Гумінський, Л. В. Фоміна, Т. Л. Полеся \\ Вінницький національний медичний університет ім. М. І. Пирогова
}

\section{ACHIEVEMENTS AND PROSPECTIVES OF THE EDUCATIONAL PROCESS ORGANIZATION IN THE CONTEXT OF EUROPEAN INTEGRATION IN VINNYTSIA NATIONAL MEDICAL UNIVERSITY BY M. I. Pyrohov}

\author{
V. M. Moroz, Yu. Y. Huminsky, L. V. Fomina, T. L. Polesya \\ Vinnytsia National Medical University by M. I. Pyrohov
}

\begin{abstract}
У зв'язку з підписанням Болонської декларації у світлі інтеграції України у Свропейський освітній простір у всіх вищих навчальних закладах, в тому числі й медичних, з 2005 року запроваджена кредитно-модульна система навчання. Разом 3 цим, з 2009 року для вищих навчальних закладів є обов'язковим запровадження основних положень європейської кредитно-трансферної системи (СКТС) та її ключових документів. Аналіз результатів навчання за кредитно-модульною системою та реалізація основних положень ЄКТС виявили необхідність оптимізації навчального процесу у світлі євроінтеграції медичної освіти. У зв'язку з коадаптацією національної системи освіти до вимог європейських стандартів у ВНМУ ім. М. І. Пирогова запропонована зміна підходів щодо кредитно-модульної системи організації навчального процесу.

In connection with European integration of Ukraine in Bologna idea convention from 2005 year the credit-modular educational system for the higher institutions is entered. From 2009 year for the higher educational establishment's introduction of fundamental principles of the European credit-transfer system (ECTS) and its basic documents are obligatory. Analysis of defects and advantages of studies by credit-modular system exposed contradiction between ECTS and its realization. In connection with the coadaptation of the national system of education to the requirements of the European standards in Vinnytsia National Medical University by M. Pyrohov Proposed change of ways of the relation to organization of educational process in the idea of the credit-modular system.
\end{abstract}

Вступ. На сьогоднішньому етапі одним з найважливіших стратегічних завдань вищої освіти України $є$ забезпечення якості підготовки фахівців на рівні міжнародних вимог. Ідея реформування медичної вищої освіти полягає в адаптації національної системи вищої освіти до європейських стандартів. Метою реформування вищої освіти є створення уніфікованих критеріїв і методологій та систем контролю, а також взаємовизнання дипломів про вищу освіту, сприяння мобільності студентів [1]. Процес євроінтеграції вимагає нових підходів до організації навчального процесу у вищих навчальних закладах, що й було задекларовано Україною у підписаній Болонській конвенції та полягає у запровадженні кредитно-модульної системи навчання.Кінцевою метою впровадження основних положень ЄКТС є конкурентоспроможність українських освітянських кваліфікацій на (с) В. М. Мороз, Ю. Й. Гумінський, Л. В. Фоміна, Т. Л. Полеся європейському ринку праці, визнання загальноприйнятої системи освітньо-кваліфікаційних ступенів, впровадження стандартизованого додатка до диплома.

Основна частина. Реформа медичної освіти - одне 3 найважливіших стратегічних завдань на сьогоднішньому етапі, основою яких є забезпечення якості підготовки фахівців на рівні міжнародних вимог. Перша спроба реалізації плану реформ у світлі євроінтеграції вищої освіти Україниздійснена 3 2005-2006 навчального року. Згідно з наказами $\mathrm{MOH}$ та $\mathrm{MO} 3$ України у всіх вишах було впроваджено кредитномодульну систему організації навчального процесу (КМС), основою якої є модульне викладання дисциплін, надання кредитів дисциплінам та зарахування ïx успішним студентам, рейтингова система оцінювання знань студентів за шкалою ECTS та конвертація оцінки в традиційну систему за чотирибальною шкалою. Другою та офіційною спробою згідно з нака- 
зом МОН України № 943 від 16.10.2009 року та листом МОН України № 1/9-119 від 26.02.2010 року запроваджено Європейську кредитно-трансферну систему (ЄКТС), метою якої є забезпечення якості вищої освіти та інтеграція національної системи вищої освіти в європейське та світове освітнє співтовариство. Основними положеннями ЄКТС є запровадження стандартів, рекомендацій та основних інструментів мобільності студентів і викладачів до вишів Свропи [1]. Відповідно до вимог ЄКТС, базовими ключовими документами для вищих навчальних закладів $\epsilon$ наявність “Каталога курсів”, “Аплікаційної форми студента", "Угоди про навчання", "Угоди про практичну підготовку та зобов'язання про якість”, “Академічної довідки”, “Додатка до диплома європейського зразка" [2]. Для університетів ЄКТС створює прозорість навчальних планів, надає допомогу при узгодженні програм навчання мобільним студентам, відображає результати навантаження та навчання, разом з цим забезпечує автономію вузам та відповідальність за якість навчання студента [4]. Слід відмітити, що реалізація ключових положень СКТС не заперечує впровадження будь-яких форм організації навчального процесу, в тому числі проведення іспитів, як додаткову форму контролю знань студентів, головне завдання - зберегти архітектуру СКТС (наявність трансферу накопичувальних кредитів при мобільності студентів між вузами-партнерами, ключових документів, статистичної уніфікованої шкали оцінок ECTS та їх конвертації у національну шкалу) [3].Аналіз 9-річного досвіду впровадження КМС у ВНМУ ім. М. І. Пирогова порівняно з традиційною системою навчання виявив ії переваги та недоліки. Перевагами КМС є підвищення мотивації студентів до навчання, контроль викладача на кожному занятті, впровадження більш гнучкої 7-бальної більш об'єктивної рейтингової шкали ЕCTS, значна активізація та оновлення методично-навчального забезпечення, в тому числі й оновлення сайтів університету та кафедр, що дає змогу студентам застосовувати інноваційне дистанційне навчання та значно активізувати самостійну роботу. Разом з позитивними змінами при впровадженні КМС недоліками $є$ дублювання та перевантаженість деканатів нормативно-звітною документацією, відсутністю університетської клініки та ін. Одною з головних причин перешкод в реалізації основних положень КМС є недостатнє фінансування вищої медичної освіти, наслідком чого є складнощі у матеріально-технічному оснащенні та недостатнє стимулювання праці викладачів. Основні проблеми медичної освіти України на сьогодні - це вкрай об- межене фінансування вищої школи, невідповідність умов навчання вимогам часу, застосування застарілих педагогічних технологій, високий рівень педагогічного навантаження викладача, низький рівень соціального захисту викладачів і студентів та ін. Для оптимізації та покращення якості медичної освіти у ВНМУ ім. М. І. Пирогова були впроваджені та затверджені Вченою радою університету зміни в організації навчального процесу: університет виступив ініціатором повернення виробничої лікарської практики студентів 4 та 5 курсів по закінченні весняного семестру, створена Типова програма з проведення виробничої практики, для оптимізації та уніфікації конвертації оцінок в бали для всіх дисциплін введено уніфіковану шкалу оцінювання успішності студентів перерахунку традиційних оцінок 3 5-бальної системи у європейську бальну шкалу оцінювання. Запроваджено єдину залікову книжку для студентів всіх факультетів очної форми навчання (індивідуальний план студента розрахований на 6 років навчання). Досвід впровадження модульних технологій навчання виявив, що модульне оцінювання не є стимулюючим фактором для усвідомлення програмного матеріалу 3 дисциплін в цілісному сприйнятті та не сприяє отриманню студентами довгострокових системних знань. Питома вага поточного оцінювання (60 \%) контролюється викладачем (іноді з малим педагогічним стажем), а підсумковий контроль знань 3 модуля (лише 40 \% від загальної суми балів) контролюється досвідченими екзаменаторами, тобто переважна частка контролю знань студентів надається молодому викладачеві на поточних заняттях з дисциплін. Таким чином, на кафедрах, що викладають дисципліни з предметів ліцензійних тестових іспитів “Крок-1" та “Крок-2", 3 2013-2014 навчального року введені класичні комісійні іспити. Адаптація до КМС полягає у проведенні поточного модульного контролю у звичайний спосіб класичні заліки (відповідно до модулів), що оцінюються за шкалою “120/80”, та класичного іспиту, який оцінюють у межах модульного контролю (від 50 до 80 балів). Враховується складова оцінка поточних занять 3 модуля та екзаменаційна оцінка, що унеможливлює суб'єктивний підхід щодо оцінювання знань студентів на іспитах. У світлі оптимізації навчального процесу з метою покращення результатів при складанні студентами малих ліцензійних інтегрованих іспитів “Крок-1" та “Крок-2" у ВНМУ ім. М. І. Пирогова створений та затверджений Вченою радою університету Центр моніторингу якості освіти. Основними засадами Центру моніторингу якості освіти $\epsilon$ проведення попереднього та передекзаменаційного 
тестування навчальних досягнень та рівня професійної компетентності студентів (інтернів). Попереднє та передекзаменаційне тестування полягає у тестуванні студентів I-VI курсів медичного, стоматологічного та фармацевтичного факультетів після завершення навчальної програми з конкретної дисципліни перед складанням іспиту (диференційного заліку) або малих ліцензійних іспитів за відкритими інформаційними банками тестових завдань Крок-1, Крок-2 та Крок-3 Центру тестування при МО3 України з метою визначення рівня навчальних досягнень та рівня професійної компетентності студентів з відповідного навчального предмета. Ректорат Вінницького національного медичного університету імені М. І. Пирогова щороку встановлює строки проведення претестувань, щороку затверджує величини критерію “склав", здійснює моніторинг за дотриманням процедури проведення претестувань, здійснює заходи щодо покращення якості підготовки студентів (інтернів) в університеті за результатами претестувань як форми оцінювання навчальних досягнень та рівня професійної компетентності. Основна стратегія створення такого центру полягає у постійному контролі якості освіти на всіх етапах навчального процесу, включно і складання попередніх та передекзаменаційних тестувань студентами (інтернами). Результати передекзаменаційного тестування (70-100 \%) конвертуються у традиційну оцінку (70-80 \% - “3”, 80,1$90 \%$ - “4", 90,1-100\% - “5") і враховуються в якості складової остаточної екзаменаційної оцінки на іспиті (диференційномузаліку). Графік проведення та результати передекзаменаційних тестувань студентів надаються всім кафедрам, деканатам та ректору для проведення аналізу навчальної діяльності студентів та викладачів. 3 метою покращення практичної підготовки студентів та оптимізації методики опанування практичних навичок на базі ВНМУ ім. М. І. Пирогова створений Тренувальний центр для опанування практичних навичок студентами та інтернами 3 клінічних дисциплін, на базі якого клінічні кафедри запроваджують сучасні тренажерні системи (у т. ч. комп'ютерні тренажери в світлі державної програми “СКІФ”), муляжі, фантоми, імітатори для діагностики, лікування та профілактики різних нозологій, Інтернет-технології з наданням пріоритету загальній практиці-сімейній медицині. 3 метою покращення підготовки спеціалістів-стоматологів планується відкриття університетської стоматологічної поліклініки як науково-навчального та лікувально-методичного центру. Профільні методичні ради та випускаючі кафедри університету постійно вдосконалюють робочі про- грами $з$ профільних дисциплін відповідно до вимог проведення практично-орієнтованих іспитів (покращена якість контрольних завдань, які надаються в ДЕК; оптимізовано оцінку знань та практичних навичок випускників (в балах); покращена клінічна підготовка під час проведення практичних занять та організації підконтрольної СРС; клінічні кафедри більше приділяють увагу оволодінню студентами практичними навичками та професійними вміннями, особлива увага акцентується на діагностиці невідкладних станів та наданні медичної допомоги на догоспітальному етапі у дорослих і дітей згідно зі стандартами та протоколами МОЗ України).

Висновки.Таким чином, 9-річний досвід впровадження КМС виявив їі недоліки та переваги. Одночасно було з' ясовано, що впровадження СКТС (європейської кредитно-трансферної системи) у навчальний процес не тотожний КМС, а є одною з багатьох форм та інструментів їі реалізації. В процесі поетапної імплементації основних положень СКТС у вищу медичну освіту України з часом відбувається коадаптація національних та європейських технологій навчання [5]. Слід зазначити, що в країнах Свропи кожен навчальний заклад використовує свої методології та підходи щодо навчання при реалізації основних принципів та положень ЄКТС. Нова концепція реформування вищої медичної освіти України полягає у можливості запровадження різних форм організації навчального процесу, ключове завдання - зберегти уніфіковану архітектуру СКТС для взаємовизнання результатів навчання та дипломів про вищу освіту (а саме наявність трансферу накопичувальних кредитів, ключових документів ЄКТС, статистичної шкали оцінок ECTS та їх конвертації у національну шкалу). Головна мета реалізації основних положень СКТС уніфікація та гармонізація національних освітніх систем вищої освіти з країнами Свропи. Крок за кроком поступово удосконалюються шляхи реформування вищої медичної освіти згідно з європейськими стандартами [6]. Головна ідея створення спільного Свропейського освітнього простору полягає у впровадженні реформ вищих навчальних закладів країн Свропи в своїх національних рамках, але виконанні уніфікованих задекларованих Болонськими угодами зобов'язань у світлі положень європейської кредитно-трансферної системи. Реформування медичної освіти України - це унікальний шанс з боку держави надати кожному студенту можливість здобути освіту європейського рівня, стати конкурентоспроможним фахівцем та мати можливість вибору місця праці у будьякій країні Свропи та світу. 


\section{Література}

1. Визначення критеріїв якості в системі безперервного професійного розвитку лікарів та провізорів на основі концепції кредитів / Ю. В. Вороненко, А. М. Сердюк [та ін.] // Медична освіта. -2007. - № 3.- С.11-15.

2. Довідник користувача ЄКТС 2009. Брюссель, 6 лютого 2009 p.-Режим доступу : http://www.bologna2009benelux.org 3. Комюніке Конференції міністрів європейських країн, відповідальних за сферу вищої освіти (Лондон, 16-19 травня 2007 року). - К., 2008. - Кн. 4 : Основні засади розвитку вищої освіти України. - С. 24-30.

4. Вища медична освіта і Болонський процес : навч.- ме- тод. та інф.-довідк. матеріали наради-семінару для наук.пед. працівників, аспірантів, магістрів (17-19 січня 2005 р.). Частина I. - Київ, 2005.-C. 112-115.

5. Болонский процесс: нарастающая динамика и многообразие (документы международных форумов и мнения европейских экспертов). - М. : Исследовательский центр проблем качества подготовки специалистов, 2002. С. 231-234.

6. Система управління якістю медичної освіти в Україні : монографія / [І. Є. Булах, О. П. Волосовець, Ю. В. Вороненко та ін.]. - Д. : АРТ-ПРЕС, 2003. 